\title{
EDITORIAL: OLD OR NEW?
}

\author{
Christopher Fox
}

TEMPO is a 'quarterly review of new music' and a previous editorial in TEMPO 279 considered where new-ness might be said to begin in the calendar. But new-ness is conceptual as well as chronological, a distinction brought into sharp focus in the current issue, ranging as it does from the apparent conservatism of James Macmillan's Symphony No.4, to the ostentatiously tech-savvy work of Brigitta Muntendorf and Stefan Prins, with, somewhere in between, a new opera by Johannes Kreidler that this erstwhile iconclast is happy to call an opera.

Is a work for symphony orchestra intrinsically less new than a work in which computer game handsets become instruments? After all, today's new technology is tomorrow's landfill and music history is littered with the remains of instrumental innovations that failed the test of time: yesterday the Mellotron, the day before that the baryton. But if new-ness goes beyond mere instrumentality how else might we conceptualise it? Music history is littered too with attempts to define radical aesthetic developments, although until recently 'experimental music' seemed to be a term that might survive. But in a fascinating public lecture at City University on 29 May 2018, Michael Nyman, whose 1974 book, Experimental Music, seemed to explain the subject so successfully, popped the experimental balloon. He revealed that the book's title was a given - it was the last in a series of books about the arts, each with 'Experimental' as the first word of their title - and so were its contents - he wrote about the music he had heard and admired in the previous few years. Experimental music was not so much a concept as a convenience.

Lauren Redhead's article adopts a different approach. Like Nyman her focus is on music that many would regard as left-field, oppositional, experimental, but she suggests that a better term might be 'exformal'. She cites the writings of Nicolas Bourriaud who describes the exformal as 'the site where border negotiations unfold between what is rejected and what is admitted, products and waste'. The business of rejection and admittance, what's in and what's out, is at the centre of our capitalist societies so the exform becomes, according to Bourriaud, 'an authentically organic link between the aesthetic and the political'.

The relationships between 'products and waste', between 'the aesthetic and the political' also inform the work of Allison Cameron, profiled in an interview with Anna Höstman. Cameron talks about her 2013 project in the Arctic, territory that for centuries has appeared to be an icy wasteland. Even today, she says, 'people do those cruises on those big ships. They go through into the Northwest passage ... and just ruin areas'. Yet, as warmer year follows warmer year, our understanding of the Arctic is changing: what was once a wasteland is becoming a crucial indicator of humanity's impact on this planet.

Elsewhere in this issue questions of old and new recur in Violetta Kostka's article on intertextuality in the music of Paweł Szymański. 
Szymański is a fascinating composer whose works incorporate elements of past musical styles; sometimes these are quite audible, sometimes they are transformed beyond recognition. As Kotzka explains, Szymański's music always operates on at least two levels (and not just because he has a fondness for bipartite forms in which the second movement seems to offer a critique of the first). These compositions are, as she says, 'musical riddles': they are 'rooted in tradition' yet also 'modern and original'. At the end of her article Kotzka draws conclusions that might apply to all these various reflections on the old and new, that they represent 'a metaphor for our human, imperfect learning about the world, our inability to reach the core of the matter, our fragmentary perception of reality'.

Once again we must mark the passing of two considerable figures from the world of new music, this time the composers Glenn Branca (1948-2018) and Dieter Schnebel (1930-2018), who died within a week of one another in May. Coincidence sometimes produces interesting contrasts, but few are as marked as those between Branca, the tough-talking convenor of electric guitar orchestras, and Schnebel, the urbane European artist-intellectual. Yet both significantly changed the way we make and think about music today.

Glenn Branca was a guitarist whose encounter with the No Wave scene in New York in the late 1970s led him to create the band that would become known as the Theoretical Girls. With Rhys Chatham he pioneered a new type of minimalism based around open-tuned electric guitars, first heard in Chatham's Guitar Trio (1977) and then developed in a series of works that Branca devised and directed himself. From the early 1980s his music started to appear regularly on independent record labels, beginning with Lesson No.1 released as an EP on 99 Records in 1980, and as his reputation spread so did his ambition. He gathered ever larger groups of guitarists to play works made up of several movements, works which he designated as 'symphonies'; Symphony No.1 was premiered in 1981, No.16 (for 100 guitars) in 2015. For much of his career Branca's music depended on his presence, to cajole his signature sound - dense, throbbing, overtone-rich - from his musicians in rehearsal, and then to perform his shamanistic conducting dance while they played.

With the death of Dieter Schnebel we have lost one of the last survivors of the generation of musicians who dominated European new music in the second half of the twentieth century. Schnebel was not only a composer but also a theologian and musicologist: his editing of the first three volumes of Stockhausen's writings, for example, played a considerable role in forming the discourse around that composer's music. He was a pioneer of new approaches to notation and the theatre of performance, particularly in the scores entitled visible music (1960/62) of which perhaps the best known is the second, for conductor and instrumentalist, which Schnebel also realised as a piece for solo conductor, Nostalgie.

His music for voices, especially the series of works with the overall titles Maulwerke and Glossalie, required singers to go far beyond the conventional vocalisation of their training. The Glossalie explore the borders between language and sound, between speaking and singing, while the Maulwerke take as their subject the vocal apparatus itself, each part focussing on different types of sound production. Later he found ways to draw his interests together, in works such as the Dahlemer-Messe, an ecumenical mass setting written for the Berlin 
parish in which he sometimes preached, or most notably, Sinfonie $X$ for large orchestra, solo soprano, contralto, tenor and bass, choir, children's voices, speakers, tape and live electronics, first heard in 1992 (Parts I and II) and then in 2005 with Part II added; the complete Sinfonie $X$ is three and a half hours long. The scale and technical demands of his work may suggest megalomania, yet in person Schnebel was never other than charming, friendly and modest. 